\title{
MORPHOLOGICAL REACTION OF SPERMATOZOA IN THE FEMALE REPRODUCTIVE TRACT OF THE RABBIT
}

\author{
J. M. BEDFORD
}

Worcester Foundation for Experimental Biology, Shrewsbury, Massachusetts, U.S.A. and Department of Physiology, Royal Veterinary College, London, N.W.1

(Received 12th February 1963)

Summary. A study of rabbit ejaculate and epididymal spermatozoa, and of spermatozoa recovered from various regions of the female tract, has revealed some consistent morphological differences in the state of the acrosome between these groups. Few acrosomes were missing or changed in epididymal or ejaculate spermatozoa. On the other hand, the acrosome was absent in spermatozoa released from the perivitelline space of fertilized ova. Uterine and tubal spermatozoa recovered 9 to 11 $\mathrm{hr}$ after insemination of ejaculates into oestrous or pseudopregnant females showed change or loss of the acrosome in a variable percentage ( 8 to $58 \%$ ). The percentage acrosome loss from uterine samples taken after insemination of aliquots from the same ejaculate into pairs of females was closely similar within each pair, though variation occurred between pairs. Consistently higher acrosome losses (mean, $33 \%$ ) were found following insemination of ejaculates collected after 1 month's sexual rest than were found after insemination of the third ejaculate from each of the same males (mean, $17 \cdot 2 \%$ ). Considerably fewer acrosomes were missing from uterine spermatozoa recovered after insemination of epididymal spermatozoa (mean, 5\%) compared to the loss after insemination of ejaculate spermatozoa (mean, $27.4 \%$ ) taken previously from the same males. Fertility trials with ejaculate and epididymal spermatozoa showed no difference in fertilization rate, or in numbers of supplementary spermatozoa, in favour of the ejaculate samples, i.e. those which showed the greater percentage acrosome changes.

In conclusion it is suggested that the quantitative variation in acrosome reaction between samples of uterine spermatozoa reflects differences in the samples, rather than differences in the female environment. The acrosome changes in the uterine and tubal spermatozoa of the domestic rabbit are probably not a morphological concomitant of capacitation, but more probably reflect impending sperm senility.

\section{INTRODUCTION}

A cap-like structure which covers the anterior surface of the sperm head has been found to occur in the spermatozoa of all eutherian mammals so far studied. 
This structure is now most commonly termed the acrosome, or acrosome cap. Its functional role during fertilization in mammals is not yet clear. Various workers, in particular Dan (1952, 1954) and Colwin \& Colwin (1957), have shown that in many invertebrates and in at least two vertebrates, the acrosomal apparatus reacts to the presence of homologous ova by the extrusion of filaments. These filaments are thought to facilitate the interaction of the spermatozoon with the ovum. However, no such reaction has been reported in the mammalian spermatozoon, either before or during fertilization. Nevertheless, the importance of the mammalian acrosome in the fertilization process may perhaps be inferred, such inference being supported, for instance, by reports of complete or partial sterility shown to occur in bulls (Teunissen, 1946; Hancock, 1949) and in boars (Bane, 1961) in association with inherited acrosome defects. It has been suggested at various times that the enzyme hyaluronidase is formed in the mammalian acrosome. Hyaluronidase is thought to fulfil some function in the fertilization process, perhaps in facilitating the passage of the spermatozoon through the cumulus oophorus. As yet, however, the experimental evidence in favour of this view remains rather inconclusive.

During a study of fertilization in the guinea-pig and in several rodents, Austin \& Bishop (1958) noticed that the acrosome was absent from those spermatozoa which had penetrated the substance of the zona pellucida, the perivitelline space or the vitellus. Some of the spermatozoa seen in the Fallopian tube fluids and cumuli of mated females also showed either loss of, or alteration in appearance of the acrosome cap. Later, similar findings in the mouse were reported by Ohnuki (1959), while Moricard (1961) has published an electron micrograph of a rabbit spermatozoon, without the acrosome, lying in the substance of the zona pellucida. In discussing their findings, Austin \& Bishop (1958) suggested that the changes observed in the acrosome of spermatozoa lying in the reproductive tract might well constitute a morphological concomitant of the capacitation process, which has been shown to be an essential prerequisite for fertilization in the rabbit and rat (Austin, 1951; Chang, 1951). Similar conclusions were also drawn by Ohnuki (1959). In view of this it seemed to be of interest to examine and compare the acrosomal morphology of rabbit ejaculate and epididymal spermatozoa with that of spermatozoa recovered from the perivitelline space of the fertilized ovum, and from the uterus and Fallopian tubes, some hours after mating or insemination.

Experiments on the fertilization of rabbit ova in vitro have shown that at least some of the spermatozoa recovered from the female tract $6 \mathrm{hr}$ or more after mating, are fully capacitated in the functional sense, i.e. for successful entry into the ovum; the presence of the cumulus oophorus, corona radiata, or some tubal factor is not necessarily required (Bedford \& Chang, 1962). In the experiments to be described, the spermatozoa were invariably recovered from the female tract between 9 and $11 \mathrm{hr}$ after insemination. At this time it might reasonably be expected that the great majority of these spermatozoa would be fully capacitated. Thus, should any specific morphological reaction take place in the rabbit spermatozoon during or as a result of the capacitation process, it would seem logical to expect that this reaction would also be manifested in a large percentage of recovered uterine spermatozoa. 


\section{MATERIALS AND METHODS}

Adult male and female rabbits of various domestic breeds were used. Females, housed in separate cages, were judged to be in oestrus according to the appearance of the vulva and from the reaction produced by vulval stimulation. The ovaries were later checked at laparotomy. Some females were made pseudopregnant by intravenous injection of $50 \mathrm{i} . \mathrm{u}$. of chorionic gonadotrophin, and used 9 to 12 days later.

Ejaculate spermatozoa were obtained from males of proven fertility by means of an artificial vagina. Epididymal spermatozoa were taken from the cauda region of the epididymis soon after six successive ejaculations. Uterine and tubal spermatozoa were obtained by flushing the uterus and Fallopian tubes with Ringer solution, 9 to $11 \mathrm{hr}$ after vaginal insemination of ejaculate or epididymal spermatozoa. Suspensions of ejaculate spermatozoa were also incubated in $20 \%$ serum-Ringer solution at $37^{\circ} \mathrm{C}$ for $12 \mathrm{hr}$, as controls for the uterine and tubal spermatozoa. Slide preparations of the spermatozoa were made by spreading one to two drops of a dilute sperm suspension upon microscope slides and drying in air. These slides were then stained in $1 \%$ Rose Bengal for approximately 5 to $6 \mathrm{hr}$. After staining, the slides were stacked and dried in air at room temperature.

To obtain supplementary spermatozoa from the perivitelline space of recently fertilized rabbit ova (PI. 1, Fig. 1), females were killed 14 to $18 \mathrm{hr}$ after mating. The ova were collected by flushing the Fallopian tubes with Ringer solution; the cumulus oophorus was removed by treatment with a solution of hyaluronidase, and the cells of the corona were removed by physical means (Bedford \& Chang, 1962). Frequently, following such treatment, supplementary spermatozoa could be seen still moving in the perivitelline space. Eggs showing the presence of several such supplementary spermatozoa were washed three times by vigorous shaking in Ringer solution, in an effort to remove any spermatozoa adhering to the external surface of the zona pellucida. These eggs were then placed in a small drop of Ringer under a binocular dissecting microscope and, using a Graafe knife and fine dissecting needle, the zona pellucida was carefully incised and the vitelline materials expressed and removed. The shell of the zona pellucida was then cut into a number of small fragments and the boundary of the area covered by these fragments etched into the glass slide. The slides were dried in air at room temperature, and stained as described above.

Examination of the spermatozoa was carried out under oil immersion at a magnification of $\times 800$ or $\times 1200$, using a bright field microscope with a light source provided by a mercury arc vapour lamp, incorporating an orange (o.y. 2) filter. This source of illumination is extremely bright for the unshielded eye, and for normal scanning of the slides the condenser was racked down, thereby reducing the light intensity. For photography or for examination of any particular detail, the condenser was brought into position of accurate focus. Photographs were taken with Kodak P.300 Panchromatic plates. During the scanning procedure, each slide was traversed twice only. By avoiding the immersion oil mark made by the first traverse no spermatozoon was assessed more than once. 
Comparative fertility trials were carried out as follows: $1 \mathrm{ml}$ aliquots of a prepared suspension of either ejaculate or epididymal spermatozoa in concentration of one million $/ \mathrm{ml}$ or $200,000 / \mathrm{ml}$, were introduced into oestrous females which had received an ovulation injection 1 to $2 \mathrm{hr}$ previously: 16 to 18 $\mathrm{hr}$ after the ovulation injection these females were killed and the tubal ova collected by flushing. These ova were then cultured for 6 to $8 \mathrm{hr}$ at $37^{\circ} \mathrm{C}$ in a

TABLE 1

PERCENTAGE ACROSOME LOSS FROM SPERMATOZOA REGOVERED AFTER RUPTURE OF WASHED FERTILIZED RABBIT OVA

\begin{tabular}{c|c|c|c|c}
\hline $\begin{array}{c}\text { Buck } \\
\text { No. }\end{array}$ & $\begin{array}{c}\text { No. of ova } \\
\text { recovered }\end{array}$ & $\begin{array}{c}\text { Total } \\
\text { spermatozoa } \\
\text { from ruptured } \\
\text { ova }\end{array}$ & $\begin{array}{c}\text { Supplementary } \\
\text { spermatozoa } \\
\text { acrosome loss } \\
(\%)\end{array}$ & $\begin{array}{c}\text { Fallopian tube } \\
\text { spermatozoa } \\
\text { acrosome loss } \\
(\%)\end{array}$ \\
\hline 136 & 11 & 99 & 96 & 16 \\
142 & 8 & 50 & 90 & 28 \\
136 & 4 & 4 & 100 & 28 \\
142 & 8 & 48 & 100 & 24 \\
134 & 8 & 24 & 100 & 37 \\
152 & 8 & 40 & 97.5 & 34 \\
133 & 7 & 49 & 98 & 13 \\
148 & 7 & 63 & 97 & 10 \\
\hline Total & 61 & 377 & 97.3 & 23.75 \\
\hline
\end{tabular}

* Fifteen hours after insemination.

medium of Ringer-glucose solution containing $20 \%$ homologous serum. Following this, any remaining granulosa cells were easily removed from the surface of the zona pellucida, and the ova were then mounted on slides with a cover glass supported by petroleum jelly. By rolling the ova and by examination at different focal depths, the numbers of supplementary spermatozoa and spermatozoa on the surface of the zona pellucida could be counted with reasonable accuracy. To check for the occurrence of normal fertilization, the ova were fixed in acetic-alcohol, stained with lacmoid (1\%; Chang, 1952) and examined for the presence of pronuclei and polar bodies.

\section{PROGEDURE AND RESULTS}

The acrosome cap of the rabbit spermatozoon is seen clearly in Pl. 1, Fig. 2. When the acrosome has been shed the exposed surface shows little affinity for the Rose Bengal stain and usually presents a whiting appearance (PI. 1, Fig. 3). In addition the absence of the cap frequently results in the appearance of narrow shoulders formed by the anterior edge of the post-nuclear cap. In a very few spermatozoa the acrosome was observed in the process of being shed. In some of these spermatozoa the acrosome was shed as a complete cap (Pl. 1, Fig. 4), while in others the acrosome appeared to be fragmenting. In view of the small numbers observed, these latter spermatozoa have been included in the 'acrosome lost' groups.

From Table 1 it can be seen that, of the spermatozoa observed following the 
PLATE 1

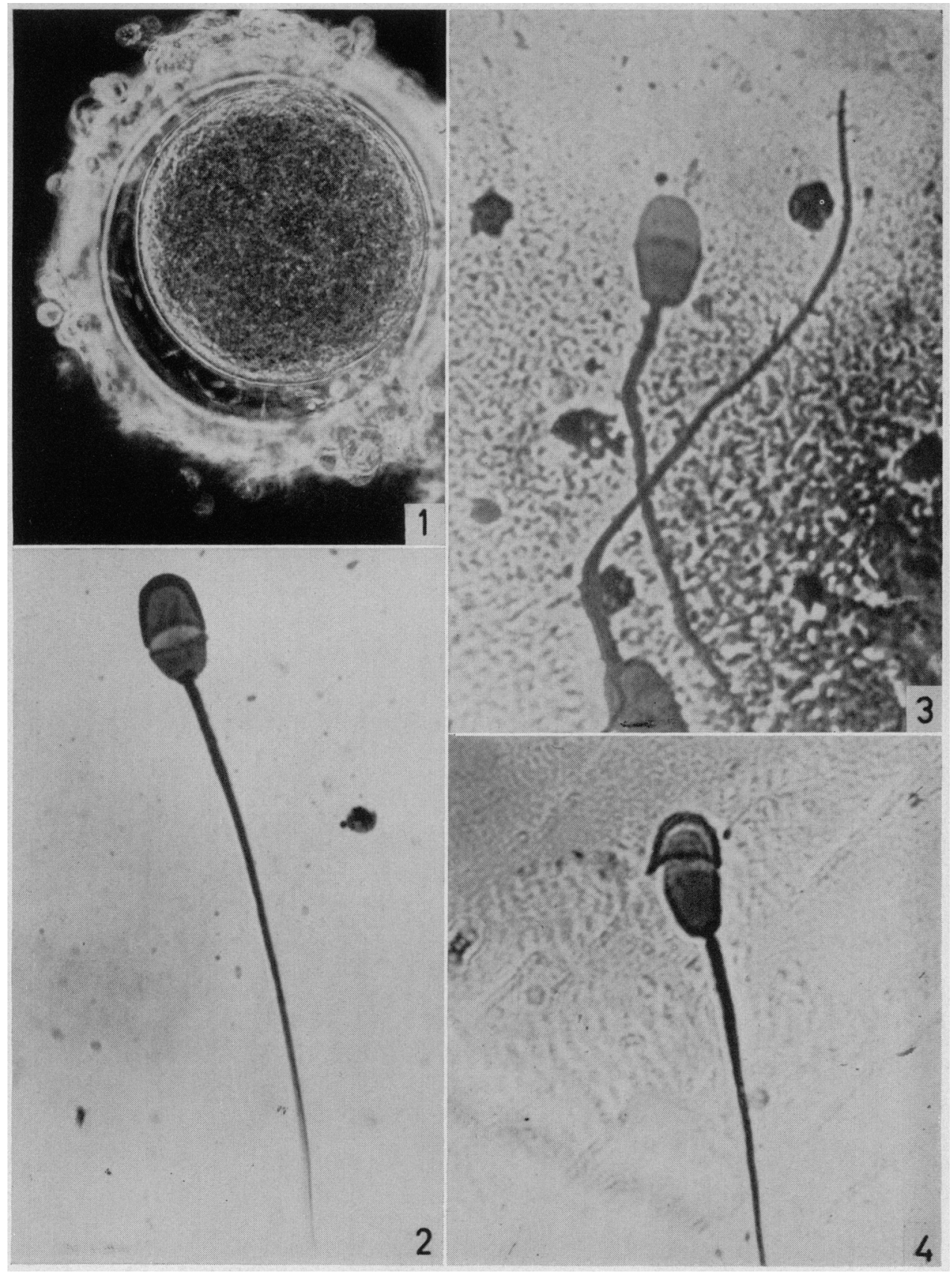

FIG. 1. Spermatozoa present in the perivitelline space of a fertilized rabbit ovum, recovered $18 \mathrm{hr}$ after mating. Several cells of the corona radiata are still adherent to the zona pellucida (phase-contrast).

FIG. 2. Rabbit ejaculate spermatozoon, showing stained acrosome and post-nuclear cap, and relatively unstained equatorial segment ( $1 \%$ Rose Bengal).

Fig. 3. Rabbit spermatozoon, acrosome missing, recovered from the uterus about $10 \mathrm{hr}$ after mating ( $1 \%$ Rose Bengal).

Fig. 4. Rabbit spermatozoon recovered from the uterus $10 \mathrm{hr}$ after mating; the elevated acrosome cap is in the process of being shed (1\% Rose Bengal).

(Facing p. 248) 
disruption of the zona pellucida, $97.3 \%$ had lost the acrosome cap. It might be expected, as a corollary of the observations of Austin \& Bishop (1958), that the acrosomes would have been absent from all these spermatozoa. However, considering the methods used here to obtain and observe the spermatozoa, it seems reasonable to suppose that the few spermatozoa which retained their acrosomesin this group had not been removed from the external surface of the zona pellucida by prior washing of the ova, but had been dislodged from the zona pellucida surface only during the rupture and dissection of this membrane.

The percentage acrosome loss in spermatozoa recovered from the uterus or

TABLE 2

PERGENTAGE AGROSOME LOSS FROM UNTREATED EJAGULATES AND FROM UTERINE AND TUBAL SPERMATOZOA, 9 TO 11 HR AFTER INSEMINATION OF THE EJAGULATE

\begin{tabular}{|c|c|c|c|c|}
\hline \multirow[b]{2}{*}{$\begin{array}{l}\text { Buck } \\
\text { No. }\end{array}$} & \multicolumn{4}{|c|}{ Acrosome loss (\%) } \\
\hline & $\begin{array}{c}\text { Ejaculate } \\
\text { spermatozoa }\end{array}$ & $\begin{array}{l}\text { Ejaculate sperm- } \\
\text { atozoa incubated in } \\
\text { Ringer's solution at } \\
37^{\circ} \mathrm{C} \text { for } 12 \mathrm{hr}\end{array}$ & $\begin{array}{c}\text { Uterine } \\
\text { spermatozoa } \\
9 \text { to } 11 \text { hr after } \\
\text { insemination }\end{array}$ & $\begin{array}{c}\text { Tubal } \\
\text { spermatozoa } \\
9 \text { to } 11 \text { hr after } \\
\text { insemination }\end{array}$ \\
\hline $\begin{array}{r}91 \\
132 \\
133 \\
120 \\
92 \\
134 \\
136 \\
120 \\
133 \\
120 \\
136 \\
138 \\
133 \\
133 \\
138 \\
136\end{array}$ & $\begin{array}{l}2 \\
1 \\
3 \\
0 \\
2 \\
3 \\
1 \\
0 \\
3 \\
0 \\
0 \\
3 \\
1 \\
0 \\
2 \\
2\end{array}$ & $\begin{array}{l}4 \\
4 \\
3 \\
2 \\
5 \\
4 \\
2 \\
0 \\
5 \\
3 \\
3 \\
2 \\
1 \\
1 \\
5 \\
4\end{array}$ & $\begin{array}{l}37 \\
50 \\
46 \\
10 \\
43 \\
58 \\
33 \\
43 \\
25 \\
27 \\
42 \\
27 \\
21 \\
25 \\
18 \\
17\end{array}$ & $\begin{array}{r}34 \\
35 \\
- \\
- \\
- \\
40 \\
37 \\
46 \\
35 \\
18 \\
- \\
- \\
25 \\
37 \\
26 \\
20\end{array}$ \\
\hline Mean & 1.5 & 3.0 & 31.4 & $32 \cdot 0$ \\
\hline
\end{tabular}

One hundred spermatozoa counted in each group.

Fallopian tubes some 9 to $11 \mathrm{hr}$ after insemination was considerably greater than that from untreated ejaculate spermatozoa, or from spermatozoa incubated at $37^{\circ} \mathrm{G}$ for $12 \mathrm{hr}$ in $20 \%$ serum-Ringer solution (Table 2). In this group, where different females were inseminated with different ejaculates, a considerable variation in percentage acrosome loss was apparent. A similar variation in percentage acrosome loss was found also in uterine spermatozoa recovered from females 9 to 11 days pseudopregnant, inseminated with ejaculate spermatozoa about $10 \mathrm{hr}$ previously (Table 3 ). However, when ejaculates were divided and inseminated into two oestrous females, or into one oestrous and one pseudopregnant female, then a close similarity was seen in the res- 
pective percentage acrosome loss in uterine spermatozoa samples recovered from each member of a pair (Table 4). Using individual ejaculates taken from

TABLE 3

PERGENTAGE AGROSOME LOSS FROM SPERMATOZOA IN THE REPRODUCTIVE TRACT OF PSEUDOPREGNANT* RABBITS 9 TO 11 HR AFTER INSEMINATION

\begin{tabular}{|c|c|c|c|c|}
\hline \multirow[b]{2}{*}{$\begin{array}{l}\text { Buck } \\
\text { No. }\end{array}$} & \multicolumn{4}{|c|}{ Acrosome loss (\%) } \\
\hline & $\begin{array}{c}\text { Ejaculate } \\
\text { spermatozoa }\end{array}$ & $\begin{array}{l}\text { Ejaculate sperm- } \\
\text { atozoa incubated in } \\
\text { Ringer's solution at } \\
37^{\circ} \mathrm{C} \text { for } 12 \mathrm{hr}\end{array}$ & $\begin{array}{c}\text { Uterine } \\
\text { spermatozoa }\end{array}$ & $\begin{array}{c}\text { Tubal } \\
\text { spermatozoa }\end{array}$ \\
\hline $\begin{array}{r}134 \\
132 \\
134 \\
92 \\
136 \\
120 \\
92\end{array}$ & $\begin{array}{l}0 \\
0 \\
1 \\
3 \\
3 \\
1 \\
0\end{array}$ & $\begin{array}{l}3 \\
0 \\
2 \\
4 \\
4 \\
1 \\
1\end{array}$ & $\begin{array}{r}20 \\
20 \\
19 \\
32 \\
59 \\
28 \\
8\end{array}$ & $\begin{array}{r}8 \\
17 \\
- \\
- \\
29 \\
25 \\
8\end{array}$ \\
\hline Mean & $1 \cdot 2$ & $2 \cdot 2$ & $26 \cdot 6$ & $18 \cdot 0$ \\
\hline
\end{tabular}

One hundred spermatozoa counted in each group.

* Nine to twelve days after ovulation injection.

each animal in a group of five males, consistently greater numbers of acrosomes were shed from uterine spermatozoa recovered after insemination of the first

TABLE 4

PERCENTAGE ACROSOME LOSS FROM UTERINE SPERMATOZOA RECOVERED 9 TO 11 HR AFTER INSEMINATION OF EJACULATES DIVIDED BETWEEN TWO FEMALES

\begin{tabular}{c|c|c|c}
\hline \multirow{2}{*}{$\begin{array}{c}\text { Buck } \\
\text { No. }\end{array}$} & $\begin{array}{c}\text { Acrosome } \\
\text { loss in } \\
\text { ejaculate } \\
(\%)\end{array}$ & \multicolumn{2}{|c}{$\begin{array}{c}\text { Acrosome loss from uterine spermatozoa } \\
(\%)\end{array}$} \\
\cline { 2 - 3 } & 1 & $A$ & $B$ \\
\hline 92 & 0 & 27 & 25 \\
132 & 0 & 22 & 17 \\
136 & 2 & 37 & 24 \\
133 & 1 & 33 & 36 \\
134 & 1 & 13 & 14 \\
132 & 3 & 13 & 7 \\
92 & 1 & 26 & $29 *$ \\
92 & 2 & 18 & $23^{*}$ \\
134 & 0 & 17 & $15^{*}$ \\
132 & 3 & $22 \cdot 5$ & $21 \cdot 3$ \\
134 & 1.3 & & \\
\hline Mean & & & \\
\hline
\end{tabular}

Two hundred spermatozoa counted in each group.

* Pseudopregnant 9 to 11 days.

ejaculate taken after 1 month's sexual rest, compared to the acrosome loss observed in uterine spermatozoa after insemination of the third ejaculate from 
each of these males (Table 5). A greater disparity was seen, however, between the percentage acrosome loss in uterine spermatozoa recovered after insemina-

TABLE 5

PERCENTAGE ACROSOME LOSS FROM UTERINE SPERMATOZOA AFTER INSEMINATION OF INITIAL AND THIRD EJACULATES RESPECTIVELY: COLLECTED FOLLOWING COMPLETE SEXUAL REST FOR 1 MONTH

\begin{tabular}{r|c|c|c|c}
\hline \multirow{3}{*}{$\begin{array}{c}\text { Buck } \\
\text { No. }\end{array}$} & \multicolumn{2}{|c|}{$\begin{array}{c}\text { Acrosome loss from initial } \\
\text { ejaculate (\%) }\end{array}$} & \multicolumn{2}{|c}{$\begin{array}{c}\text { Acrosome loss from third } \\
\text { ejactuate (\%) }\end{array}$} \\
\cline { 2 - 4 } & $\begin{array}{c}\text { Untreated } \\
\text { spermatozoa }\end{array}$ & $\begin{array}{c}\text { Uterine } \\
\text { spermatozoa }\end{array}$ & $\begin{array}{c}\text { Untreated } \\
\text { spermatozoa }\end{array}$ & $\begin{array}{c}\text { Uterine } \\
\text { spermatozoa }\end{array}$ \\
\hline 92 & 10 & 32 & 3 & 26 \\
136 & 3 & 31 & 1 & 13 \\
142 & 4 & 27 & 0 & 16 \\
143 & 4 & 33 & 2 & 23 \\
145 & 5 & 42 & 2 & $17 \cdot 2$ \\
\hline Mean & 5.2 & $33 \cdot 0$ & 1.5 & 8 \\
\hline
\end{tabular}

Two hundred spermatozoa counted in each group nine to eleven hr after insemination.

tion of individual ejaculates from each of ten males, and that occurring after insemination of epididymal spermatozoa taken from the same males soon after

TABLE 6

PERGENTAGE ACROSOME LOSS IN UTERINE SPERMATOZOA 9 TO 11 HR AFTER INSEMINATION WITH INITIAL EJAGULATE SPERMATOZOA, AND WITH EPIDIDYMAL SPERMATOZOA TAKEN FROM THE CAUDA EPIDIDYMIS AFTER SIX SUCGESSIVE EJAGULATIONS

\begin{tabular}{c|c|c|c|c}
\hline \multirow{2}{*}{$\begin{array}{c}\text { Buck } \\
\text { No. }\end{array}$} & \multicolumn{2}{|c|}{$\begin{array}{c}\text { Acrosome loss from ejaculate } \\
\text { spermatozoa }(\%)\end{array}$} & \multicolumn{2}{|c}{$\begin{array}{c}\text { Acrosome loss from epididymal } \\
\text { spermatozoa (\%) }\end{array}$} \\
\cline { 2 - 5 } & $\begin{array}{c}\text { Untreated } \\
\text { spermatozoa }\end{array}$ & $\begin{array}{c}\text { Uterine } \\
\text { spermatozoa }\end{array}$ & $\begin{array}{c}\text { Untreated } \\
\text { spermatozoa }\end{array}$ & $\begin{array}{c}\text { Uterine } \\
\text { spermatozoa }\end{array}$ \\
\hline 381 & 2 & 23 & 1 & 5 \\
- & 3 & 24 & 0 & 3 \\
133 & 6 & 26 & 0 & 4 \\
379 & 2 & 32 & 2 & 9 \\
112 & 4 & - & 2 & 6 \\
92 & 1 & 26 & 3 & 6 \\
134 & 0 & 30 & 1 & 2 \\
132 & 0 & 36 & 1 & 5 \\
136 & 1 & 31 & 1 & 5 \\
142 & 4 & $27 \cdot 4$ & $1 \cdot 5$ & $5 \cdot 0$ \\
\hline Mean & $2 \cdot 3$ & & & 5 \\
\hline
\end{tabular}

Two hundred spermatozoa in each group.

six successive ejaculations. In each case fewer than $10 \%$ of the acrosomes were lost in uterine spermatozoa recovered following insemination of epididymal $\mathrm{C}^{* *}$ 
spermatozoa, whereas an average of $27.4 \%$ were shed from uterine spermatozoa taken after insemination of ejaculates.

In fertility trials, females inseminated with ejaculate spermatozoa showed neither a higher fertilization rate nor greater numbers of supplementary or zona pellucida surface spermatozoa, when compared with females inseminated similarly, but with epididymal spermatozoa (Table 7). On the contrary, in many cases, these values were slightly higher in the latter group.

TABLE 7

FERTILIZATION RATE AND NUMBERS OF SPERMATOZOA PRESENT ON OVA RECOVERED 18 TO 20 HR AFTER INSEMINATION OF SPERMATOZOA FROM FIRST EJAGULATE OR FROM THE CAUDA EPIDIDYMIS* RESPECTIVELY

\begin{tabular}{|c|c|c|c|c|c|c|}
\hline Treatment & $\begin{array}{l}\text { Buck } \\
\text { No. }\end{array}$ & $\begin{array}{c}\text { No. } \\
\text { females }\end{array}$ & $\begin{array}{l}\text { No. } \\
\text { ova }\end{array}$ & $\begin{array}{c}\text { Ova } \\
\text { fertilized } \\
(\%)\end{array}$ & $\begin{array}{c}\text { No. } \\
\text { supplementary } \\
\text { spermatozoa }\end{array}$ & $\begin{array}{c}\text { No. } \\
\text { zona pellucida } \\
\text { spermatozoa }\end{array}$ \\
\hline \multirow[t]{2}{*}{$\begin{array}{l}\text { Ejaculate spermatozoa } \\
\text { Insemination of } \\
1,000,000 \text { spermatozoa } \\
\text { in } 1 \mathrm{ml} \text { serum/Ringer }\end{array}$} & $\begin{array}{l}11 \\
12 \\
13 \\
14\end{array}$ & $\begin{array}{l}2 \\
2 \\
2 \\
2\end{array}$ & $\begin{array}{l}24 \\
10 \\
17 \\
14\end{array}$ & $\begin{array}{l}66 \cdot 6 \\
80 \cdot 0 \\
94 \cdot 0 \\
92 \cdot 8\end{array}$ & $\begin{array}{l}3 \cdot 3 \\
0 \cdot 6 \\
2 \cdot 0 \\
3 \cdot 9\end{array}$ & $\begin{array}{l}2 \cdot 2 \\
0 \cdot 5 \\
7 \cdot 8 \\
5 \cdot 6\end{array}$ \\
\hline & & 8 & 65 & $83 \cdot 3$ & $2 \cdot 4$ & $4 \cdot 0$ \\
\hline \multirow[t]{2}{*}{$\begin{array}{l}\text { Insemination of } \\
200,000 \text { spermatozoa } \\
\text { in } 1 \mathrm{ml} \text { serum/Ringer }\end{array}$} & $\begin{array}{l}16 \\
17 \\
18 \\
19\end{array}$ & $\begin{array}{l}2 \\
2 \\
2 \\
2\end{array}$ & $\begin{array}{l}13 * \\
17 \\
18 \\
22\end{array}$ & $\begin{array}{r}46 \cdot 1 \\
88 \cdot 2 \\
100 \cdot 0 \\
89 \cdot 0\end{array}$ & $\begin{array}{l}0 \cdot 0 \\
1 \cdot 2 \\
0 \cdot 66 \\
4 \cdot 3\end{array}$ & $\begin{array}{l}2 \cdot 0 \\
3 \cdot 6 \\
1 \cdot 6 \\
2 \cdot 25\end{array}$ \\
\hline & & 8 & 70 & $80 \cdot 8$ & 1.5 & $2 \cdot 7$ \\
\hline \multirow[t]{2}{*}{$\begin{array}{l}\text { Epididymal spermatozoa } \\
\text { Insemination of } \\
1,000,000 \text { spermatozoa } \\
\text { in } 1 \mathrm{ml} \text { serum/Ringer }\end{array}$} & $\begin{array}{l}11 \\
12 \\
13 \\
14\end{array}$ & $\begin{array}{l}2 \\
3 \\
2 \dagger \\
2\end{array}$ & $\begin{array}{r}13 \\
29 \\
7 \\
17\end{array}$ & $\begin{array}{l}92 \cdot 3 \\
82 \cdot 7 \\
85 \cdot 7 \\
94 \cdot 0\end{array}$ & $\begin{array}{l}7 \cdot 7 \\
3 \cdot 4 \\
0 \cdot 8 \\
4 \cdot 8\end{array}$ & $\begin{array}{r}14 \cdot 0 \\
2 \cdot 6 \\
1 \cdot 3 \\
8 \cdot 9\end{array}$ \\
\hline & & 9 & 66 & $88 \cdot 5$ & $4 \cdot 2$ & $6 \cdot 7$ \\
\hline \multirow[t]{2}{*}{$\begin{array}{l}\text { Insemination of } \\
200,000 \text { spermatozoa } \\
\text { in } 1 \mathrm{ml} \text { serum/Ringer }\end{array}$} & $\begin{array}{l}16 \\
17 \\
18 \\
19\end{array}$ & $\begin{array}{l}2 \\
2 \\
2 \\
2\end{array}$ & $\begin{array}{r}19 \\
9 \\
20 \\
16\end{array}$ & $\begin{array}{c}94 \cdot 0 \\
100 \cdot 0 \\
95 \cdot 0 \\
91 \cdot 34\end{array}$ & $\begin{array}{l}0 \cdot 66 \\
4 \cdot 0 \\
3 \cdot 0 \\
0 \cdot 33\end{array}$ & $\begin{array}{l}3 \cdot 3 \\
6 \cdot 7 \\
2 \cdot 7 \\
1 \cdot 5\end{array}$ \\
\hline & & 8 & 64 & $95 \cdot 1$ & $2 \cdot 0$ & 3.5 \\
\hline
\end{tabular}

\section{DISGUSSION}

Although Rose Bengal is held to have a certain affinity for lipid materials, it also stains many tissues in an apparently non-specific way. Hence, it is not possible to relate, histochemically, the observed difference in the staining reaction of the acrosome, post-nuclear cap and tail, with that of the equatorial segment (Pl. 1, Fig. 1) or of the exposed surface of the anterior sperm head following removal of the acrosome cap (Pl. 1, Fig. 2).

It seems clear from the results in Table 2 that the environment of the female 
tract may produce a change in the acrosome or in the components binding the acrosome to the nuclear surface, such that the acrosome is partially or completely shed from some spermatozoa during the period following mating or insemination. The spermatozoa that have penetrated the zona pellucida of the rabbit ovum have also been shown to lack the acrosome cap. From these facts, it might at first seem reasonable to suppose that spermatozoa which have shed the acrosome prior to fertilization are those which have been fully capacitated and are therefore fully prepared for entry into the ovum. This seems extremely unlikely, however, for the following reasons. Firstly, it appears that acrosomes are lost from rabbit spermatozoa with equal facility in oestrous or in pseudopregnant uteri; yet it has been shown conclusively that rabbit spermatozoa are not capacitated, in the functional sense, while residing in the pseudopregnant uterus (Chang, 1958). The contents of the uterine lumen of pseudopregnant animals do not appear to influence the fertilizing ability of spermatozoa previously capacitated in an oestrous uterus (unpublished results). Thus it would seem that failure to capacitate in the pseudopregnant uterus is more likely due to the absence of an essential uterine factor, not necessarily associated with the activity by which the acrosomes are removed in the uterus. In the second place the percentage of acrosomes shed up to the time of ovulation, after insemination of epididymal spermatozoa, was consistently and considerably less than the percentage acrosome loss following insemination of ejaculate spermatozoa from the same males. If the spermatozoa devoid of acrosomes represented the fully capacitated, and hence the potential number of fertilizing spermatozoa in a sample, it would be expected that, when using minimal numbers for insemination, this difference might well become apparent in the fertilization rate, and in the numbers of supplementary spermatozoa present. However, the trials carried out to test this proposition have shown no bias in favour of ejaculate spermatozoa, either in the fertilization rate or in the number of supplementary spermatozoa, taken as absolute numbers or in ratio to the numbers of spermatozoa on the surface of the zona pellucida. The latter relationship is perhaps the more relevant in that, within limits, the mean number of spermatozoa on the surface of the zona pellucida may be taken as approximately proportional to the number of available spermatozoa in the vicinity of the egg at the time of fertilization. The similarity in percentage acrosome loss after insemination of pairs of females with aliquots from the same ejaculate (Table 4) suggests that the degree of loss may depend only in a general way on the uterine environment, and additionally, but more specifically, on some quality inherent in a particular sperm sample. The small but consistent difference in percentage acrosome loss following the insemination of the first and third ejaculate samples taken after a prolonged period of sexual rest (Table 5) together with the more marked disparity in percentage acrosome loss between uterine samples recovered after insemination of ejaculate or of epididymal spermatozoa, suggests that this difference in reaction may be associated with the relative ages of particular sperm samples. The loss of acrosomes from spermatozoa in bull, stallion and boar ejaculates has been described previously (Blom, 1945; Hancock, 1955, 1956). In those cases, spermatozoa which showed rupture or loss of the acrosome were considered to be degenerating or dead. In 
the present study, though relatively few acrosomes were missing in untreated ejaculates, it seems possible that some activity of the uterine environment served to accentuate or reveal a state of impending senility in a certain proportion of the sperm population. Although the available evidence is somewhat conflicting, it seems that immotile spermatozoa inseminated into the vagina of the rabbit do not generally reach the uterus and Fallopian tubes. Thus while spermatozoa, which later showed acrosomal changes in the uterus, may well represent the more senile members of the inseminated sample, it seems likely nevertheless that these spermatozoa did exhibit a moderate degree of motility at the time of insemination.

In this investigation, when assessing the state of the acrosome cap, it was possible to observe the head of most but not all spermatozoa on the slides prepared from uterine flushings. In a few cases the sperm head was obscured as a result of phagocytosis by uterine leucocytes. Subsequently, however, studies with the electron microscope (in preparation) have shown that the acrosome cap, and frequently also the plasma membrane covering the acrosome, apparently remains intact in a majority of the phagocytized spermatozoa, recovered and fixed about $10 \mathrm{hr}$ after mating. Thus although the results in Tables 2 to 6 do reflect the extent of acrosome change in the free uterine sperm population, this degree of acrosome change must be considered rather high in terms of the total uterine sperm population.

In conclusion, in the light of the results discussed here, it seems that, in the domestic rabbit at least, visible changes in the acrosome seen in a proportion of uterine spermatozoa, most probably do not constitute a morphological concomitant of the capacitation process as such. The evidence presented here suggests rather that these changes may be a morphological manifestation of a senile state in a certain proportion of the sperm population. It seems fairly certain that the acrosome cap is shed from rabbit spermatozoa by the time the perivitelline space is reached. The exact moment at which the acrosome is discharged from these spermatozoa remains uncertain.

\section{AGKNOWLEDGMENTS}

This work was supported in part by grants from the Population Council Inc, and by Grant G.M. 10529-01 from the U.S. Public Health Service.

I would like to thank $\mathrm{Dr}$ M. C. Chang for much helpful advice, and also Professor E. G. Amoroso, F.R.s. for his assistance in reading the manuscript.

\section{REFERENGES}

Austin, C. R. (1951) Observations on the penetration of the sperm into the mammalian egg. Aust. $\mathcal{F}$. Sci. Res. B, 4, 581 .

Austin, C. R. \& Bishop, M. W. H. (1958) Role of the rodent acrosome and perforatorium in fertilization. Proc. roy. Soc. B, 149, 241.

Bane, A. (1961) Acrosome abnormality associated with sterility in boar. Proc. IVth int. Congr. Anim. Reprod., The Hague, p. 810.

Bedford, J. M. \& Ghang, M. G. (1962) Fertilization of rabbit ova "in vitro". Nature, Lond. 193, 898.

BLom, E. (1945) Spontaneous detachment of the galea capitis in spermia of bull and stallion. Scand. vet. Tidschr. 35, 779 . 
Chang, M. G. (1951) The fertilizing capacity of spermatozoa deposited into the Fallopian tubes. Nature, Lond. 168, 697.

Chang, M. C. (1952) Fertilizability of rabbit ova and the effects of temperature "in vitro" on their subsequent fertilization and activation "in vivo". J. exp. Zool. 121, 351.

Ghang, M. G. (1958) Capacitation of rabbit spermatozoa in the uterus with special reference to the reproductive phases of the female. Endocrinology, 63,619.

Colwin, A. L. \& Colwin, H. L. (1957) Morphology of fertilization: acrosome filament formation and sperm entry. The Beginnings of Embryonic Development, p. 135. Publ. 48 of A.A.A.S., Washington, D.C.

DAN, J. C. (1952) Studies on the acrosome. I. Reaction to egg water and other stimuli. Biol. Bull., Woods Hole, 103, 54.

DAN, J. C. (1954) Studies on the acrosome. II. Acrosome reaction in starfish spermatozoa. Biol. Bull., Woods Hole, 107, 203.

Hancock, J. L. (1949) Evidence of an inherited seminal character associated with infertility of Friesian bulls. Vet. Rec. 61, 308.

Hancock, J. L. (1955) The disintegration of bull spermatozoa. Vet. Rec. 67, 825.

Hancock, J. L. (1956) The morphology of boar spermatozoa. F. R. micr. Soc. 76, 84.

Moricard, R. (1961) Superpénétration spermatique de le membrane pellucide et observations en microscopie électronique d'oeufs fécondés de lapine. Proc. IVth int. Congr. Anim. Reprod., The Hague, p. 736.

OHNuki, Y. (1959) Some morphological observations of mouse spermatozoa in relation to insemination. Zool. Mag. (Tokyo), 68, 275. Biol. Abstr. (1960) 35, 46462.

Teunissen, G. H. B. (1946) Een afkijking van het acrosoom (kopkap) bij de spermatozoiden van een stier. Tidschr. Diergeneesk. 71, 292. 